\title{
EVALUATION OF STATE STIMULATION MEASURES FOR INVESTMENT-INNOVATIVE ACTIVITY OF SMALL ENTERPRISES IN RUSSIA
}

\author{
Yuri Anatolievich Doroshenko* \\ Belgorod State Technological University named after V.G. Shukhov, Russia \\ Irina Vladimirovna Somina \\ Belgorod State Technological University named after V.G. Shukhov, Russia \\ Yulia Sergeevna Krasnokutskaia \\ Belgorod State Technological University named after V.G. Shukhov, Russia
}

Within the current paperwork, we analyze an active system of state support for small entrepreneurship in Russian Federation, modern institutions and instruments of implementation of state policy for stimulation of small business. We have conducted an analysis of activity results of Russian funds for development of investment-innovative processes in small and medium sized business. Ways for improvement of state support measures for small entrepreneurship in Russia were proposed.

Key words: Small enterprises, Innovative-investment activity, System of state support, Tax stimulation, Tax privileges, State institutes of development

\section{INTRODUCTION}

In recent years, issues of small business attract attention of scientists and experts more often. Small business is an important element of market economy, without it the sustainable development of country is impossible. An effective market household is credible only if vast amount of entrepreneurial structures is in place.

Formation of favorable conditions for development of small business provides population with incomes from independent household activity, and budgets - with tax incomes. Orientation at small business improves psychological mood in society, which shapes noneconomic compound of governmental policy effect in analyzing area. That is why many-sided support of small business industry can be related to number of core destinations of economic development of mesoand macro economical systems.

According to data of Ministry of economic development of RF, two out of five Russian companies are small sized business. Each sixth, and with account of individual entrepreneurs, each fifth occupied in economy - is worker of small and medium sized business. In country's small entrepreneurship sector the fifth share of country's GDP is being produced.

Many Russian economists and sociologists (A.I.
Ageev, Y.K. Banenov, A.V. Beresnevoy, M.G. Lapusta, K.Liuhto, T.G. Philosovoi and others $[01,03,07$,etc.]) conducted researches on modern conditions and problems of small entrepreneurship development, insufficient efficiency of state measures of support in Russia was revealed. Accordingly, it rises the necessity of further detailed analysis of current Russian mechanism of state stimulation of innovative-investment activity of small entrepreneurship subjects, and also the development of arrangements for its modernization and evolvement.

\section{METHOD}

Nowadays economically developed countries has working mechanisms of multidimensional state support of small business. Stimulation of innovative-investment activity of small enterprises is conducted in various forms, in particular, by stimulation of manufacturing of the most priority product types, provision of tax privileges, subsidies of preferential bank crediting, establishment of informative-consultative and R\&D centers, development of insurance system, organization of material and technical supplement. An important role belongs to admission and execution of laws, development and implementation of specific complex programs. 
The system of state support for small entrepreneurship currently established in Russia includes:

- governmental regulations aimed at support and development of small entrepreneurship;

- state apparat, which represents an assemblage of governmental institutional structures in charge for development of small entrepreneurship, provided the implementation of governmental policy in that sphere and conducting the regulation of small entrepreneurship industry and management of its support infrastructure;

- governmental infrastructure of small entrepreneurship support, including non-commercial and commercial organizations, established with or without state participation, which activity is initiated, encouraged and supported by government, and intended for implementation of state support aimed at development of small entrepreneurship.

In our opinion, formed scientifically theoretical statements and practical mechanisms should serve as foundation for further development and modernization of state support system for innovative-investment activity of small entrepreneurship subjects of Russian Federation.

\section{MAIN PART}

In circumstances of demand for realization of long-term strategy of socially-economical development of Russia, which set for transition of Russia's economy to innovative development model, an important task is governmental assistance to establishment in Russia of effective complex of small innovative business.

Government of RF conducts the work aimed at renewal of country's development strategy till 2020 , which has to provide Russia an access at a new level in establishment of modern effective and competitive economy, which provides a deserved life standard for citizens. The main task is increasing of resource potential of small business by its core compounds: labor, financial, production and innovative [14]. Increasing in resource potential of small entrepreneurship will enable our country to solve an important task of longterm socially-economical development strategy of Russia till 2020 year, which related to overcoming of raw-oriented bias of economy and its transition to innovative rails of development.

Depending on direction of state influence on small business subjects we can define two groups of tax policy instruments: tax privileges and tax stimulations (Figure 1) [16].

Tax privileges have compensational character and create equal conditions for economy's subjects, which, due to some circumstances, have unequal possibilities. Unity of implementation goals and influence approach on taxpayer behavior allows equating economical privileges with kind of economical stimulations as financial incentives. Economical privileges, or incentives, are advisable to mark as "tax subsidies», because they represent additional incomes of government in economy.

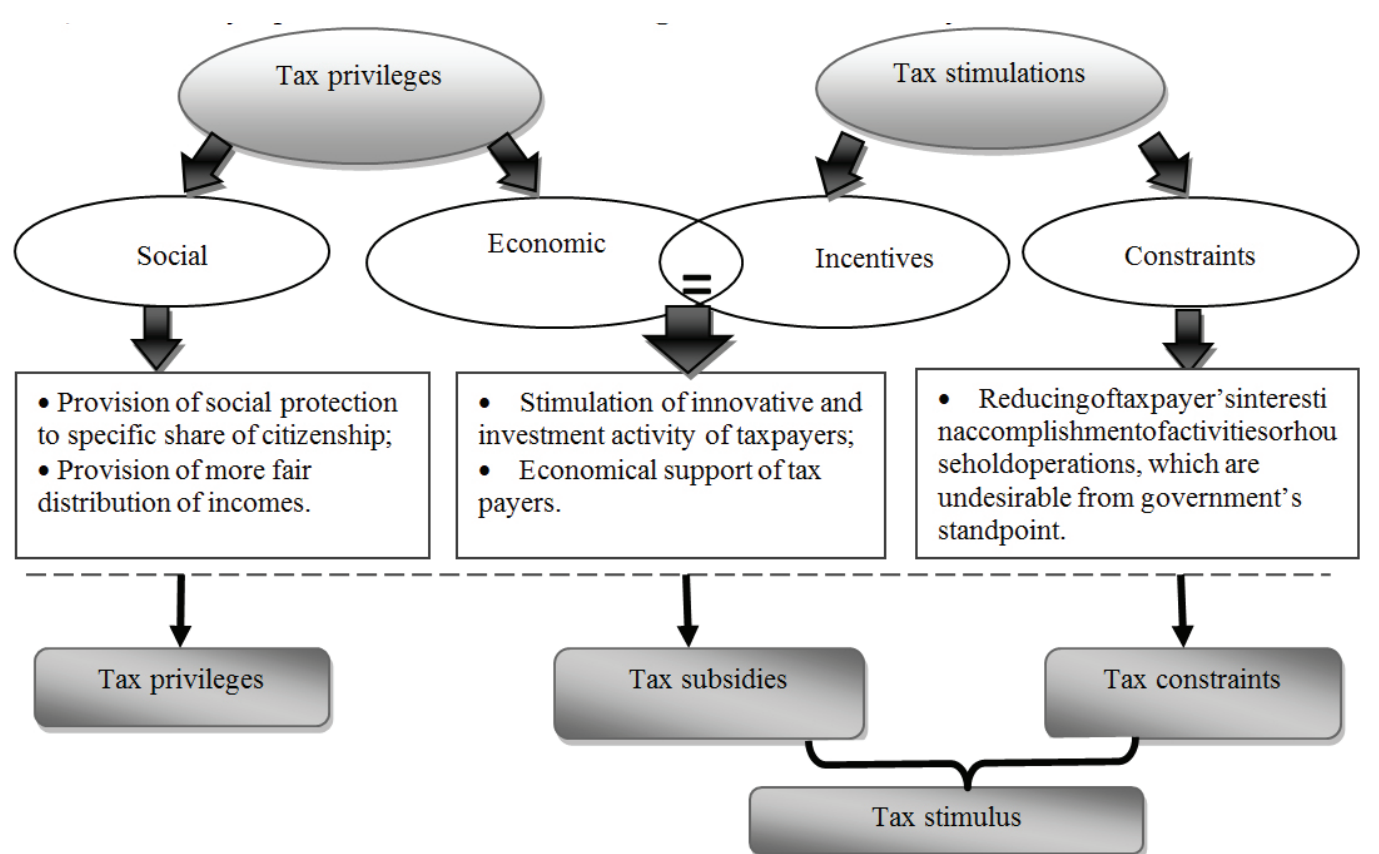

Figure 1: Types of tax policy instruments depending on direction of governmental leverage Journal of Applied Engineering Science 14(2016)3, 391 
Practical meaning of tax privileges and tax stimulations is contained in fact that their provision leads to direct reducing of state budget's incomes, account of which allows analyzing an efficiency of tax stimulation instruments of innovative activity, conduct the evaluation of stimulations in comparison with dynamic of socially economic indicators. With purpose of definition of settled tax stimulations content and their practical importance for small innovative business we represented the systematization of instruments for tax stimulations of innovative and investment activity in Russian Federation (Table 1) [16].

Table 1: Systematization and classification of current tax stimulus in dependence of representation form

\begin{tabular}{|c|c|c|}
\hline Type & Leverage approach & Stimulus end users/Form of representation \\
\hline \multirow{4}{*}{ 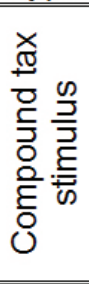 } & \multirow{3}{*}{$\begin{array}{l}\text { Taxation order, } \\
\text { incorporated by territorial- } \\
\text { industrial indication }\end{array}$} & $\begin{array}{l}\text { Residents of specific economic zones (SEZ) of } \\
\text { technically-implementation type }\end{array}$ \\
\hline & & Residents of SEZ of industrial-manufacturing type \\
\hline & & Participants of innovative project «Skolkovo» \\
\hline & Simplifiedtaxationorder & Small organizations of all economic sector \\
\hline \multirow{12}{*}{ 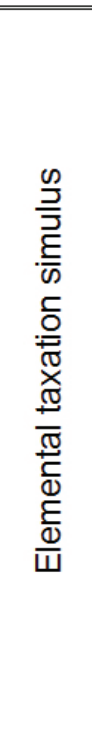 } & Taxpayers compositions & $\begin{array}{l}\text { Exemption of state R\&D centers from taxation on organizational } \\
\text { property }\end{array}$ \\
\hline & \multirow[t]{3}{*}{ Taxation object } & $\begin{array}{l}\text { Exemption of researches and (or) development engineering from } \\
\text { added value tax }\end{array}$ \\
\hline & & $\begin{array}{l}\text { Exemption of importing no-domestic-analogue technological } \\
\text { equipment (from Government of RF's list) from added value tax }\end{array}$ \\
\hline & & $\begin{array}{l}\text { Exemption of newly put in operation organizations, which have } \\
\text { high energy efficiency (according to Government of RF'slist) from } \\
\text { property tax }\end{array}$ \\
\hline & \multirow[t]{6}{*}{ Taxation base } & Exemption of target financing funds, grants from taxation \\
\hline & & Depreciation bonus \\
\hline & & Non-linear approach to write-off for depreciation \\
\hline & & Elevating coefficient for depreciation rate \\
\hline & & Privileged approach to account of R\&D expenses \\
\hline & & Formation of reserve for forthcoming R\&D expenses \\
\hline & Tax rates & Not stipulated \\
\hline & Term of tax payment & Investment tax credit \\
\hline
\end{tabular}

In result of conducted research it was discovered that prevailing share of tax stimulus is aimed at development of innovative activity of large entrepreneurial structures due to terms and conditions of provision do not consider a financial-economic potential of small business. Establishment of additional instruments of tax stimulation of small organizations will positively influence not only other economical subjects, but also the whole country, in general, by guaranteeing it a stable inflow of tax incomes in future and increasing of domestic products competitiveness.

Currently various institutions function in Russian Federation, which have to maintain development of innovative entrepreneurship. For implementation of investment support of venture companies Fund for assistance of small enterprises in R\&D industry (Fund for innovations promotion) was established. The core tasks of Fund are:

- conducting of state policy for development and support of small enterprises in R\&D sphere;

- provision of direct financial, informative and other assistance to small innovative organizations, which implement projects in elaboration and developing of new types of knowledge-intensive products and technologies based on intellectual property belonged to these organizations;

- creation and development of infrastructure for support of small innovative entrepreneurship;

- attraction of non-budget investments in industry of small innovative entrepreneurship;

- preparation of personnel (including involvement of youth into innovative activity) [11].

Within there solution of these tasks annually fund provide an assistance to more than 1500 small business enterprises. Cost evaluation of Fund's activity is represented in Table 2 . 
Table 2: Dynamics of support amount for small and medium seized entrepreneurship in Russia by Fund for innovations promotion

\begin{tabular}{|c|c|c|c|}
\hline \multicolumn{2}{|c|}{ Date } & $\begin{array}{l}\text { Quantity of small and } \\
\text { medium sized subjects }\end{array}$ & $\begin{array}{l}\text { Sum of provided support to subjects } \\
\text { of small and medium sized business, }\end{array}$ \\
\hline \multirow{4}{*}{2015} & 01.01 .2015 & 18080 & 96880 \\
\hline & 01.04 .2015 & 18841 & 99494 \\
\hline & 01.07 .2015 & 18322 & 102217 \\
\hline & 01.09 .2015 & 17725 & 105167 \\
\hline \multirow{4}{*}{2014} & 01.01 .2014 & 19322 & 95998 \\
\hline & 01.04 .2014 & 19329 & 98180 \\
\hline & 01.07 .2014 & 18871 & 99142 \\
\hline & 01.10 .2014 & 18353 & 95027 \\
\hline \multirow{4}{*}{2013} & 01.01 .2013 & 21945 & 82271 \\
\hline & 01.04 .2013 & 21653 & 88129 \\
\hline & 01.07 .2013 & 20169 & 93308 \\
\hline & 01.10 .2013 & 19969 & 97196 \\
\hline \multirow{4}{*}{2012} & 01.01 .2012 & 20688 & 73722 \\
\hline & 01.04 .2012 & 20610 & 70935 \\
\hline & 01.07 .2012 & 20254 & 66924 \\
\hline & 01.10 .2012 & 20690 & 72979 \\
\hline \multirow{4}{*}{2011} & 01.01 .2011 & 9958 & 34289 \\
\hline & 01.04 .2011 & 13296 & 46022 \\
\hline & 01.07 .2011 & 17298 & 62010 \\
\hline & 01.10 .2011 & 19165 & 68750 \\
\hline
\end{tabular}

In purposes of assistance to technological development and innovational receptivity of Russian business Trade-industrial chamber of Russian Federation has established Fund of innovative entrepreneurship development, which allows to connect to resources of external R\&D base and search the ideas and technologies in external market, thus significantly reduce financial and time resources.

An important role in system of small innovative business support in Russia belongs to JSC «Russian Bank of small and medium-sized business support» (SC «SME Bank»). In particular, SC «SME Bank» has been implementing governmental program of financial support for small and medium entrepreneurship (SME) since 2004 and is a guider of state resources for small and medium-sized business in the country's territory.

Bank's strategic purpose is provision of support to Russian entrepreneurs for diversification of Russian economy's structure, its modernization with emphasize on development of innovative compound, increasing of its competitiveness, development of citizenship's self-occupation, establishment of qualified new work places, increasing of GDP and tax incomes in federal and local budgets based on results of SME activity; formation of confident middle class of society with conscious position to social and economic development of one's region and country, in general [12].

Bank's basic tasks in support of SME are:

1) provision and maintenance of equal access possibilities for small and medium entrepreneurship subject to open and long-term financial resources throughout the whole territory of Russian Federation, including regions with difficult social and economic situations and mono-cities

2) provision of maximum wide specter of forms and approaches to support of SME through partner banks and various types of infrastructural organizations;

3) provision of access to credit resources for prior segments of SME, which are highly in demand for support: manufacturing sector of SME, modernization, innovative and resource-saving technologies, socially and regionally important project of SME, therefore, promoting the changes of industrial credit structure [12].

Financial support of SME is conducted on basis of two-level system though widespread network of partners, which includes partner-banks and infrastructural organizations (leasing companies, 
factoring companies and micro-financing companies). Support is provided to organizations and individual entrepreneurs related to categories of SME subjects and corresponding requirements of Federal law «About development of small and medium entrepreneurship in Russian Fed- eration» dated by 24.07.2007 № 209-FL [08]. Within the table 3 we present the results of work conducted by SC «SME Bank» in conditions of implementation of the Program of financial support for small and medium entrepreneurship.

Table 3: Summary of «Program of SME financial support» implementation

\begin{tabular}{|l|c|c|}
\hline \multirow{2}{*}{ Indicator } & \multicolumn{2}{|c|}{ Period of program implementation } \\
\cline { 2 - 3 } & On 01.10.2015. & During the whole period \\
\hline \hline Amount of assets, provided to SME subjects, bln.rub. & 105,2 & 565,0 \\
\hline Number of SME subjects, companies & 17725 & 53414 \\
\hline Average weighted rate for SME, \% & 13,3 & - \\
\hline Long-term crediting, \% & 81,0 & - \\
\hline Warranty, p. & 28 & 30 \\
\hline
\end{tabular}

With all that in mind SC «SME Bank» defined the further target segments:

1. Regions with priority of governmental development (Fareast FD, North-Caucasus FD, Crimea FD).

2. Support of SME subjects, which conducts their activity in mono-cities of «red» and "yellow» areas (these areas are defined by State Order from the 29th of July 2014 № $1398-p$ as $1^{\text {st }}$ and $2^{\text {nd }}$ categories of inhabited locality [04]).

3. SME subjects (residents and management companies of industrial parks).

4. SME subjects, which produce goods and provide services for large companies.

At the Figure 2 we presented the amounts of assets, which are provided by SC «SME Bank» for support and development of target segments.

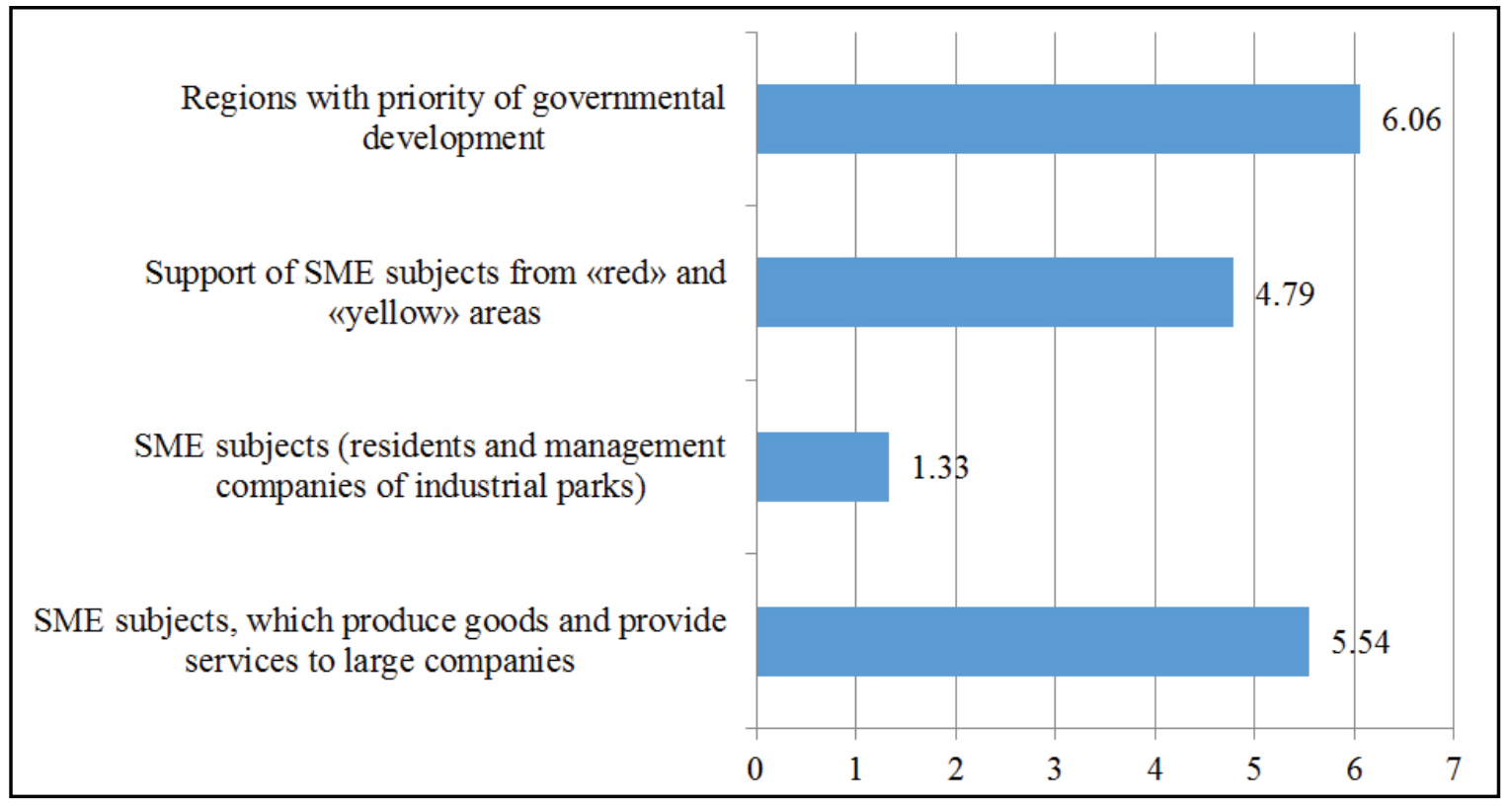

Figure 2: Assets, provided for target segments by SC «SME Bank», bln.rub

Alignment of state support instruments of SC «SME Bank» and Non-commercial organization «Fund for mono-cities development» provides new opportunities for SME subjects, which implement investment projects with amount of investments more than $250 \mathrm{mnl}$.rub. (Figure 3, g
Let's examine structure of portfolio for support of small and medium entrepreneurship in dependence on the following factors:

1. Regional structure of portfolio for support of SME subjects (Figure 4). 


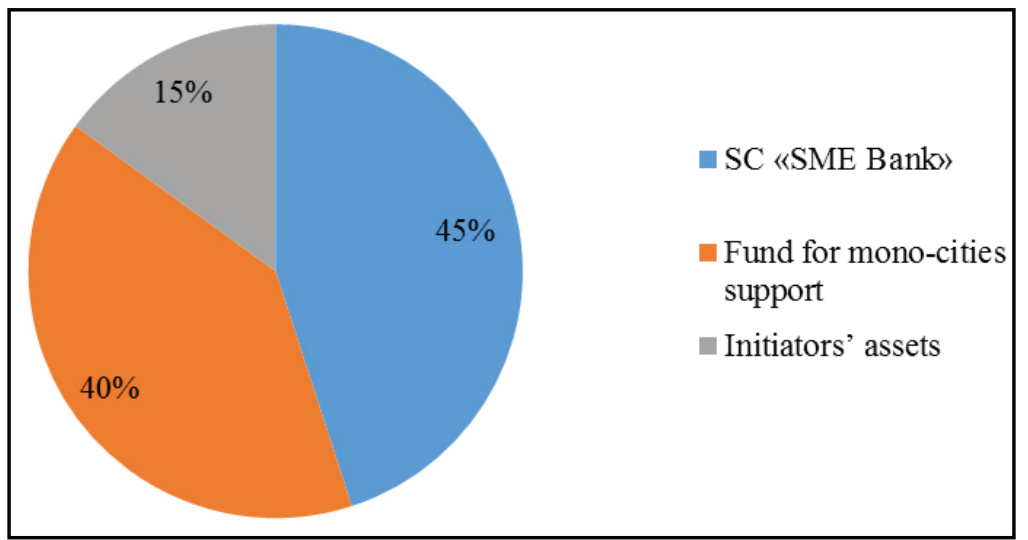

Figure 3: Structure of monetary assets investments in development of SME

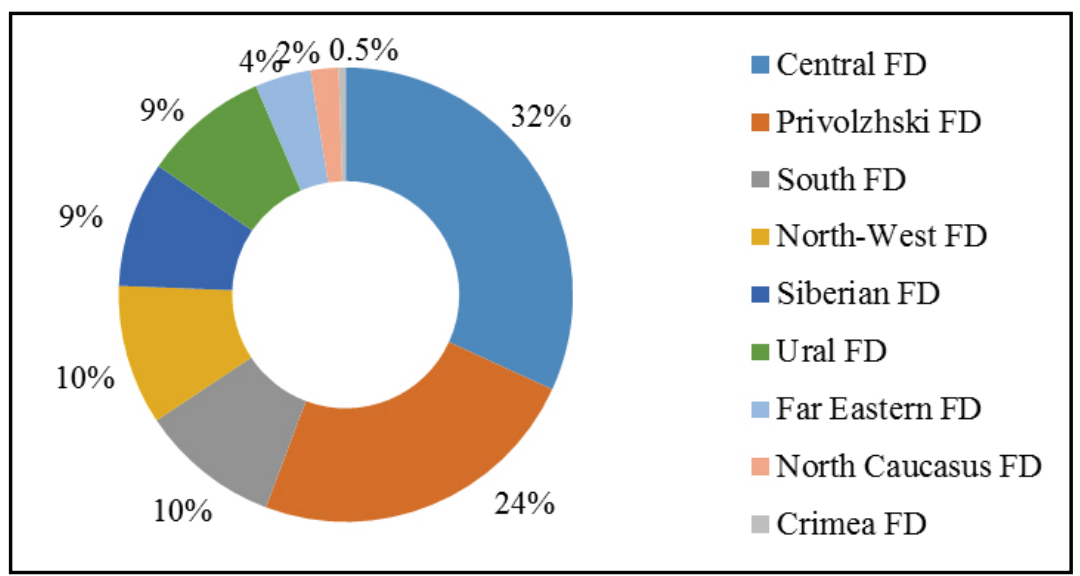

Figure 4: Regional structure of portfolio for support of SME subjects

Table 4: Combination of state support instruments of SC «SME Bank» and Non-commercial organization «Fund for mono-cities development»

Current diagram demonstrates that the biggest unit weight in regional structure of portfolio for support of SME subjects belongs to Central and Privolzhski federal district.

\section{2) Industrial structure of portfolio} for support of SME subjects (Figure 5)

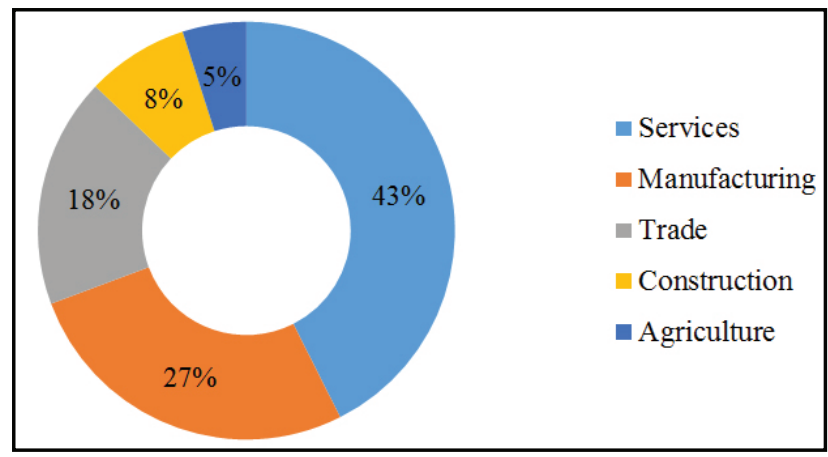

Figure 5: Industrial structure of portfolio for support of SME subjects
In context of industrial structure a maximum share in portfolio for support of SME subjects belongs to services, manufacturing and trade.

3) Structure of portfolio for support of SME subjects by time duration (Figure 6 ).

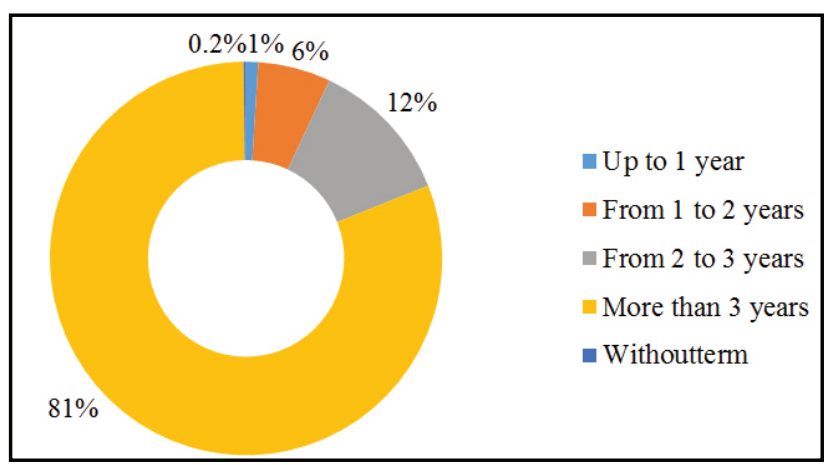

Figure 6: Structure of portfolio for support of SME subjects by time duration 
Table 4: Combination of state support instruments of SC «SME Bank» and Non-commercial organization «Fund for mono-cities development»

\begin{tabular}{|c|c|c|}
\hline Criteria & SC «SME Bank» & $\begin{array}{l}\text { Non-commercial organization «Fund } \\
\text { for mono-cities development» }\end{array}$ \\
\hline Participation form & $\begin{array}{l}\text { Provision of financing within } \\
\text { Program through parent } \\
\text { bank by two-levels system }\end{array}$ & $\begin{array}{l}\text { Participation in authorized capital of } \\
\text { project's initiator; } \\
\text { Provision of monetary assets in form of } \\
\text { loan to project's initiator. }\end{array}$ \\
\hline Term & up to 7 years & up to 8 years \\
\hline Amount & not more than 150 mln.rub. & $\begin{array}{l}\text { more than } 100 \text { mln.rub., but not more } \\
\text { than } 1000 \mathrm{mln} \text {. rub. ( } 40 \% \text { from total } \\
\text { project's cost) }\end{array}$ \\
\hline Rate & $\begin{array}{l}\text { from } 11,4 \% \text { to } 15,25 \% \\
\text { annually }\end{array}$ & $5 \%$ annually \\
\hline Goals & $\begin{array}{l}\text { Purchasing and/or repair } \\
\text { of basic assets, purchasing } \\
\text { of buildings/constructions, } \\
\text { reconstruction of } \\
\text { buildings/constructions and } \\
\text { financing of current activity } \\
\text { (up to 100\%) }\end{array}$ & $\begin{array}{l}\text { Purchasing and/or repair of basic } \\
\text { assets, purchasing } \\
\text { of buildings/constructions, land } \\
\text { patches, constructions of buildings/ } \\
\text { constructions, reconstruction of } \\
\text { buildings/constructions, partially } \\
\text { financing of current activity. Fund's } \\
\text { assets cannot be used in following } \\
\text { purposes: refinancing of current credits } \\
\text { and loans of initiator and (or) other } \\
\text { project's } \\
\text { participants, financing of project } \\
\text { documentation development, R\&D and } \\
\text { practice works, and creation of } \\
\text { nonmaterial actives. }\end{array}$ \\
\hline Participation with own assets & & $\begin{array}{l}\text { Not less than } 15 \% \text { from total cost of } \\
\text { investment project }\end{array}$ \\
\hline Support & $\begin{array}{l}\text { On term and conditions of } \\
\text { partner bank } \\
\text { Subject of small } \\
\text { entrepreneurship have } \\
\text { opportunity to obtain a } \\
\text { guarantee from SC «SME } \\
\text { Bank» up to } 50 \% \text { of credit } \\
\text { amount (main debt), } \\
\text { provided by bank, but not } \\
\text { more than } 1 \text { bln. rub. }\end{array}$ & $\begin{array}{l}\text { Guarantee, beyond/past/recall bank } \\
\text { guarantee } \\
\text { State guarantee from Russian } \\
\text { Federation subject, } \\
\text { Other forms of guarantee }\end{array}$ \\
\hline $\begin{array}{l}\text { Main criteria for picking of } \\
\text { borrower }\end{array}$ & $\begin{array}{l}\text { Correspondence with } \\
\text { requirements of FL « About } \\
\text { development of small and } \\
\text { medium entrepreneurship in } \\
\text { Russian Federation» dated } \\
\text { by } 24.07 .2007 \text { № } 209-F L \\
\text { Absence of history of } \\
\text { non-paid payment } \\
\text { documents in tax payments } \\
\text { and accounts of SME subject }\end{array}$ & $\begin{array}{l}\text { Share of town-making organization } \\
\text { ownership (direct or indirect) in } \\
\text { project's initiator capital is not less than } \\
50 \% \text { Absence of overdue (unregulated) } \\
\text { debt in tax payment, dues and other } \\
\text { obligations to budgets of RF } \\
\text { Absence of project's initiator registra- } \\
\text { tion and firm, which is controlling } \\
\text { subject of project's initiator, in country } \\
\text { or within territory, which provides } \\
\text { privilege taxation order } \\
\text { Taxation either not demand for } \\
\text { exposure of information or not ask for } \\
\text { provision of information during financial } \\
\text { operations (off-shore areas) }\end{array}$ \\
\hline
\end{tabular}


As we can see, in structure of portfolio for support of SME subjects by time duration the biggest unit weight (with significant gap) belongs to subject with more than 3 years duration.
4) Structure of portfolio for support of SME subjects by amounts of financial support (Figure 7)

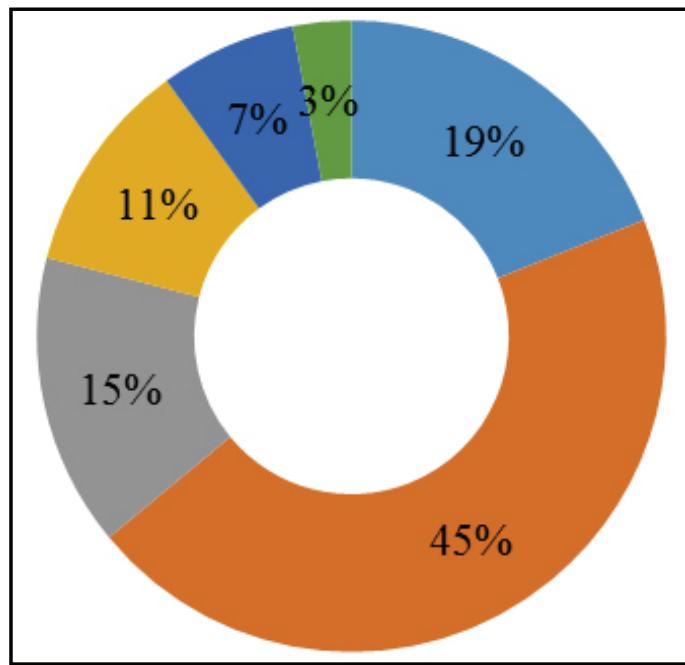

Up to $1 \mathrm{mln}$. rub

From 1 to $5 \mathrm{mln} \mathrm{rub}$

From 5 to $10 \mathrm{mln}$ rub

From 10 to $20 \mathrm{mln}$ rub

From 20 to $50 \mathrm{mln} \mathrm{rub}$

More than $50 \mathrm{mln}$ rub

Figure 7: Structure of portfolio for support of SME subjects by amounts of financial support

Therefore, the prevailing share in structure of portfolio for support of SME subjects by amounts of financial support belongs to subjects from 1 to $5 \mathrm{mln}$ rub. In general, currently Ministry of eco- nomic development of RF implements the following core mechanisms of governmental support for SME (Table 5) [02].

Table 5: Mechanisms for governmental support of SME

\begin{tabular}{|c|c|}
\hline Mechanism of governmental support of SME & Essence of mechanism \\
\hline Finances & $\begin{array}{l}\text { grants for beginners (in priority - jobless, } \\
\text { fired, etc); } \\
\text { subsidies for governmental micro financial } \\
\text { organizations and guarantee funds }\end{array}$ \\
\hline Modernization & $\begin{array}{l}\text { - } \text { subsidizing of credits percent rates; } \\
\text { - } \text { subsidizing of new equipment purchasing; } \\
\text { - equipment leasing; }\end{array}$ \\
\hline Innovatie infrastructure & $\begin{array}{l}\text { - } \text { centers of cluster development; } \\
\text { - } \text { regional centers of engineering; } \\
\text { - } \text { prototyping centers; } \\
\text { - centers of certification, standardization and } \\
\text { experiments. }\end{array}$ \\
\hline Export & $\begin{array}{l}\text { - regional centers for export support; } \\
\text { - regional integrated centers; }\end{array}$ \\
\hline Social initiatives & $\begin{array}{l}\text { - } \text { subsidizing of socially-oriented SME } \\
\text { subjects; } \\
\text { - } \text { subsidizing of Centers for day-time kids } \\
\text { staying; pre-school educational centers; } \\
\text { - youth entrepreneurship, including centers of } \\
\text { innovative creativity; } \\
\text { - } \quad \text { cultural custom and traditions. }\end{array}$ \\
\hline Informative-consultative support & - Centers for entrepreneurship support \\
\hline Special infrastructure & $\begin{array}{ll}\text { Business-incubators, industrial parks } \\
\text { (including private) and technical parks }\end{array}$ \\
\hline
\end{tabular}


As we can see, by current moment the multi-directional system of measures for support and development of small entrepreneurship has been established in Russia. Nevertheless, based on $[10,5,6,15]$, let us propose several suggestions upon its modernization:

1. We suppose that it will be reasonable to expand the practice of financial support of small and middle enterprises by providing to entrepreneurs the subsidies for compensation of expenses on development of business-plans, provision of guarantees for small businesses via warranty fund's assets, development of subsidies on compensation of share of credits percent rates.

2. An actual compound of financial mechanism must be a maintenance of equality in participation of small business in trades and tenders for state order, in first turn, its innovative part. It is necessary to develop an infrastructure of support of small businesses in maintenance of functioning for system of regional order through organization of centers for purchasing products from small enterprises, provision of consultancy on cooperation with state customers.

3. It is reasonable to strengthen an activity of preventive mechanisms against corruption with purpose of administrative barriers reduction.

4. In purposes of innovative-investment activity stimulation we have to widen a practice of budget support for subjects of small and middle enterprises.

5. It is necessary to finalize an establishment of content infrastructural system for support of small entrepreneurship at all levels (with consideration of prior development at municipal level). In process of development of infrastructural objects in mid-term perspective it is feasible to accent the one's attention on maintenance of complex consultant support for investment-innovative projects of small enterprises from their development stage till implementation.

6. It is necessary to develop system of informational support for small and medium enterprises by conduction of enlightenment work infield of financial grammar for beginning and active entrepreneurs (roundtables, conferences, seminars, partaking in mass media) and regular filling of informational data bases in non-usable spaces of state property (free, for rent, for sale) etc. In general, informational support of small enterprises should be implemented on basis of possibilities and coordination of activities of all informational networks, which specialize in accumulation and processing of appropriate information.

\section{CONCLUSION}

By that means, currently in Russia are being implemented various programs of governmental support of small enterprises. Maintenance is provided in forms of monetary sibsidies, grants; tutoring (on free basis, or with partially expenses coverage); internships; privileged leasing; business centers services; privileged/free outsourcing (external accounting and/or law services); previleged/free of charge participation in fairs and exhibitions, etc. We suppose that implementation of gathered positive experience and expanditure of mechanisms for support of investment-innovative activity, proposed within this paperwork, will allow small enterprises to reach a new level in quality of development.

\section{SUMMARY}

All in all, the input of small enterprises in development of Russia's economy is determined by its flexibility and mobility of reaction of change of market demant. Small business is faster in innovations utilization. Specifically with it development we bind our hopes for stimulation of structural overhaul of national economy and achievement of social stability in russian society. Currenty the system for support of small and medium buziness has been formed in our country. Programmed events of innovative-investment stimulation implemented through state institutes of development have multi-sided character and are accompanied by significant financial support. Nevertheless, a significantly low level of results from activity of innovative and investment segment of small and medium enterprises in Russia demands an improvement of forms and approaches of state support. In purpose of access maintenance for investors and start-up assets to the whole range of investmennt-financial instruments we propose to developm administrativelegal, tax, anti-corruptional and managemental mechanisms of support. 


\section{ACKNOWLEDGEMENTS}

The article was published with the financial support from Ministry of Education and Science of the Russian Federation within the framework of state assignment to the project \#26.1511.2014K "Theory and methodology of managing innovational and investment processes in small business enterprises."

\section{REFERENCES}

1) Ageev, A.l. (1991) Entrepreneurship: issues of property and culture. Moscow: Science, pp: 106.

2) An official cite of Ministry of Economic development of Russia. Directions of state support for small and medium enterprises in 2015 year. economy.gov.ru/minec/activity/sections/smallbusiness/, retrieved on April 3th, 2015

3) Beresneva, A.V. (2005) Role of small business in development of economy. EKO, pp: 25-32.

4) Decree of Government of the Russian Federation about List of single-enterprise municipalities of RF (mono-cities)" of 29th of July 2014 Volume \#1938-p.

5) Doroshenko, Y.A., Bukhonova, S.M., Somina, I.V., Manin, A.V. (2014) Modernization of model for initiation of investment projects as a factor of balanced maintenance of region's investment-innovational activity. Journal of Applied Engineering Science, 12(4): 265272.

6) Doroshenko, Y.A., Somina, I.V., Komissarov, S.A., Doroshenko, S.Y. (2015) The Essence and Characteristics of Investment Processes in Small Innovative Enterprises. Asian Social Science, 11(6): 185-191.

7) Lapusta, M.G. and Y.L. Starostin (1998) Small entrepreneurship. Moscow: Infra, pp: 220.

8) Law of the Russian Federation "About development of small and medium enterprises in Russian Federation" of 24th of July 2007 Volume 209-FL.

9) Liuhto, K. (2000) Influence of volume, age or industrial affilation of enterprise and it's efficiency. Economic issues, 1: 87-96

10) Maiorov, A.A. (2011) About the question of development of regional organizational-fi- nancial mechanism of small business development. Financies and credit, 15: 66-74.

11) Official web-site of the Fund for assistance of small forms of enterprises in R\&D industry. www.fasie.ru/, retrieved on September 16th, 2015

12) Official web-site of JSC "Russian Bank of small and medium enterprises". www.mspbank.ru/ru/, retrieved on October13th, 2015

13) Philosopha, T.G. (2011). About the question of development of market mechanisms of investment support for small and medium enterprises, about accelerated depreciation and increasing of competitiveness of Russia's national business. Leasing, 1: 4-13.

14) Research of perspective for development of resource potential of small business on period till 2020: theory, methodology, practice. www.gostorgi.ru, retrieved on October 1th, 2015

15) Romanovich, M.A., A.A. Rudichev and L.G. Romanovich (2011) Venture investment in innovative enterprises abroad and in Russia. Messenger of Belgorod state technological unversity n.a. V.G.Shukhov, 4: 124-127.

16) Yagudina, E.V. Kosov M.E. (2015) Tax regulation of innovtive activity. Moscow: UNITIDANA, pp: 214.

Paper sent to revison: 15.04.2016.

Paper ready for publication: 03.07.2016. 